\title{
The Implementation of Adaptive Physical Education Program for Blind Students at SMP Modern Islamic School Surakarta
}

\author{
Rahmat Subroto ${ }^{1}$, Lusi Hikmawati ${ }^{1}$, Tri Lestari ${ }^{1}$, Nanda Dewi Surtikanthi ${ }^{1}$, Riska Fatmawati ${ }^{1}$, \\ Yochidamai Akhsanitaqwim ${ }^{1}$, Sugini ${ }^{1}$ \\ ${ }^{1}$ Sebelas Maret University, Indonesia
}

\begin{abstract}
In the era of the Covid-19 pandemic, the government implemented a distance learning system for students at all levels of education. This has an impact on various changes in learning methods, including for the subjects of Physical Education, Sports, and Health. The importance of learning sports during the pandemic is the right of every student, including students with special needs. In fact, children who need special services are often excluded from teaching and learning activities in physical education. So adaptive physical education is needed so that it can serve the learning needs of blind students and lead students to achieve excellent health. To overcome the persistence of the above problem, the authors implemented an adaptive physical education program aimed at blind students at Junior High School Modern Islamic School (SMP MIS) Surakarta. The main program is train students to do adaptive rhythmic gymnastics. This program consisting of Ayo Pahami (Lets Understand), Ayo Praktikkan (Lets Practice), and Ayo Lanjutkan (Lets Continue) which are carried out online through the WhatsApp Group. In general, this program implementation activities can run well. This is evidenced by the results of written test and also performance test. Quantitatively, the average students score is 60 while the average teachers score is 84 for the written test, and the average students score for performance test is 71,2 which is considered as skilled. Qualitatively, all students understand and can memorize the whole movements of the rhythmic gymnastics. Habituation and parental/teacher guidance is needed to boost students' ability in practicing the movements so that their motor skills can improve progressively. We also arrange ETAS organizational structure that aims to encourage students to continue their rhythmic gymnastics habits and is expected new extracurricular in the future.
\end{abstract}

Keywords: adaptive physical education, blind students, rhythmic gymnastics

\section{Research Background}

In the era of the COVID-19 pandemic, the Indonesian government implemented a distance learning system for students at all levels of education. This has an impact on various changes in learning methods, including for the subjects of Physical Education, Sports, and Health. Given the fact that physical distancing is needed during this 
pandemic, students are advised to study and do sports that are individual and can be done at home without

involving many people (Oliver, 2020). Students also need sports training that is suitable with the learning objectives and effective during a pandemic.

In general, sports that are relevant to be carried out during a pandemic are physical and neural exercises in order to maintain health stability. COVID-19 infection can result in death if a person is also suffering from other complications. According to Prasetyo (2013), sports activities can improve health and prevent complications such as heart disease, type 2 diabetes, osteoporosis, cancer, obesity and injuries. In addition, physical activity in sports can also reduce risk factors for chronic disease, improve brain function, stimulate new nerve growth, and reduce stress levels (Pane, 2015; Santoso and Anandaputra, 2017).

The importance of learning Physical Education, Sports, and Health during the pandemic is the right of every student, including students with special needs (persons with disabilities). But in fact there are still many assumptions that children with special needs may not be able to do sports. Children with special needs are considered unable to carry out any activities, including sports. Children who need special services are often excluded from teaching and learning activities in physical education. Sports is actually needed by children with special needs because it can optimize physical function, minimize deconditioning syndrome (a set of symptoms that cause decreased functional capacity in several body systems due to immobilization/ decreased body movement over a long period of time), improve their well-being, and improve social skills. Apart from being at risk of experiencing various physical and psychological health problems, special needs student especially blind students who are not used to playing sports may also experience problems in orientation and mobility skills which are very important for their independent life (Utomo, 2016).

One case where the needs of blind students have not been prioritized in the aspect of physical health is what happened in the Junior High School Modern Islamic School (SMP MIS) Surakarta. The school which is located at RE. Martadinata Street Number 293, Sewu, Jebres, Surakarta is one of the inclusion schools in Surakarta that serves the blind in the learning process. SMP MIS Surakarta has received a Government Ordinance as an inclusion school since 2014. This has resulted in the receipt of inclusive grants from the government. According to the results of interviews with Special Guidance Teachers at SMP MIS Surakarta, the grant funds have accommodated the needs for learning media and academic assistance, while the needs related to the physical health of blind students have not been optimally accommodated. So far, blind students at SMP MIS Surakarta only warm up during Physical Education, Sports, and Health subjects.

Based on the background above, adaptive physical education is needed to serve the learning needs of blind students and lead students to achieve excellent health. 
Adaptive physical education is an adaptation of general physical education program according to the unique characteristic of each person. The adaptive physical education program is very important to support self-actualization and encourage personal and social development (Winnick \& Porretta, 2017).

The authors offer adapted sports training for blind students. The main program is to train students to do adaptive rhythmic gymnastics. The package of activities includes Lets Understand, Lets Practice, and Lets Continue. The author focuses on increasing the knowledge and skills of adaptive sports by providing tailored rhythmic gymnastics videos for blind students. This implementation program at SMP MIS Surakarta is not only expected to help blind people to actively exercise independently, but also expected to provide provisions for Special Guidance teachers and Sports teachers in guiding the blind students.

\section{Methodology}

The program of adaptive physical education for blind students at SMP MIS Surakarta was implemented via WhatsApp group. Currently, SMP MIS Surakarta serves 11 students with special needs. Five of them are blind students, consisting of 3 totally blind and 2 low vision students. The following table shows data of blind students, special guidance teachers, and sports teachers at SMP MIS Surakarta who were targeted in this program.

Table 1. List of Participants in the Adaptive Physical Education Program at SMP MIS Surakarta

\begin{tabular}{|c|c|c|}
\hline No. & Name & Status \\
\hline 1. & Alya Febriani & Totally blind student \\
\hline 2. & Juliana Ira Astuti & Totally blind student \\
\hline 3. & Lionel Ramadhan & Low vision student \\
\hline 4. & Mayla Putri Permata & Totally blind student \\
\hline 5. & Yahya Ardhiansyah & Low vision student \\
\hline 6. & Drs. M. Ali Darokah & Headmaster \\
\hline 7. & Fitria Nur Aryani, S. Pd. & Special Guidance Teacher \\
\hline 8. & Siti Rachmawati, S.Pd. & Special Guidance Teacher \\
\hline 9. & Hudi Ari S, S.Pd. & Special Guidance Teacher \\
\hline 10. & Dwi Sarono, S. Pd. & Sports teacher \\
\hline
\end{tabular}

The participants were following the program from their home. This is intended to ensure that there is no physical contact between all participants. This program was 
implemented on August $10^{\text {th }} 2020$ until September $30^{\text {th }}$ 2020. All the activity above have been finished on September $30^{\text {th }} 2020$. To evaluate each activity, the author have been developed several indicators. Data collection techniques used in this program are including written test and performance test with minimum completeness criteria of 60 . This means that participants who successfully get score 60 and above are considered understand and / or skilled.

The written test is used to assess the participants' understanding of the Lets Understand socialization presented. The written test is given in the form of multiple choice questions totaling 10 numbers, each number weighing 10 points. The questions list can be seen at https://bit.ly/2QWayB9.

The performance test is used to assess the success of the training. The performance test is carried out every two sessions of the Lets Practice activity finished. This test is carried out by assigning students to practice rhythmic gymnastics movements that have been taught independently. Then each student is asked to upload the independent practice activity to Google Drive and sent the link to the WhatsApp Group. The uploaded videos were observed by the team to judge what percentage of movements were properly practiced. The aspects assessed include: Orderliness of Movement Sequences, Movement accuracy, Movement-Lyrics Compatibility, Movement-Rhythm Compatibility, and Movement Flexibility. Each aspect weighing 20 points.

Table 2. The Program Implementation Stage

\begin{tabular}{|c|l|l|}
\hline No. & \multicolumn{1}{|c|}{ Activity } & \multicolumn{1}{c|}{ Description } \\
\hline 11. & Preparation & $\begin{array}{l}\text { Internal coordination, program designing, song lyrics } \\
\text { preparation, song recording, and guidance book preparation. }\end{array}$ \\
\hline 2. & MoU signing & External coordination with the school \\
\hline 3. & Lets Understand & $\begin{array}{l}\text { Explaining the importance of sport for blind people, showing the } \\
\text { series of activity, and giving motivation to be active in sport by } \\
\text { inviting an outstanding athlete with disabilities (Ni Made Arianti } \\
\text { Putri) }\end{array}$ \\
\hline 4. & Lets Practice & $\begin{array}{l}\text { Giving the tutorial video of an adaptive rhythmic gymnastics } \\
\text { (watch at youtube.com/watch?v=J9or6PdTi7k . This video is } \\
\text { completed with a song lyrics that explain the series of movement } \\
\text { and guidance book to practice each movement. This sub } \\
\text { program occurs for 6x meetings. }\end{array}$ \\
\hline 55. & Lets Continue & $\begin{array}{l}\text { Giving rewards for the best 3 participants and forming the ETAS } \\
\text { organization (Expert Team of Adaptive Sport). This sub program } \\
\text { aims to encourage students to continue their rhythmic } \\
\text { gymnastics habits and is expected to be the initial } \\
\text { extracurricular activities namely adaptive sports for blind } \\
\text { students. }\end{array}$ \\
\hline
\end{tabular}

\section{Results and Discussion}


Adaptive physical education is a physical education program tailored to the unique characteristics of an individual which is very important to support selfactualization and encourage optimal personal and social development (Winnick \& Porretta, 2017). The adaptive physical education training program at SMP MIS Surakarta is implemented based on the principles of blind learning as proposed by Lowenfeld (1952) which includes concrete experiences, learning by doing, and conceptual integration.

The adaptive physical education program implemented in SMP MIS Surakarta is in the form of rhythmic gymnastics. Rhythmic gymnastics was chosen because it is a type of sport that involves all parts of the body actively and can be done anywhere and anytime with easy-to-find facilities. Generally, rhythmic gymnastics requires the use of a considerable degree of flexibility and strength, and requires a high degree of development in these specific components. The development of strength and flexibility might allow students to perform more skillfully (Douda et al., 2002).

The rhythmic gymnastics adapted in this program contain song lyrics that describe the movements being practiced. The gymnastics also contains oral explanations about how to practice each movement so that blind students can perform these movements independently. Although the movement type in this adaptive rhythmic gymnastics is a simplified movement, but has its own objectives according to the needs and characteristics of the blind. Some of those objectives are practicing confidence in footsteps, body balance, hand-foot coordination, and improving posture.

Furthermore, here we show the results of the written test (Lets Understand assessment) which contains the initial knowledge of students and teachers after being given socialization about the importance of adaptive physical education. The filling out of this form is done before students practice the gymnastics movement as a basis for knowledge and motivation so that students are more enthusiastic about joining the program. 

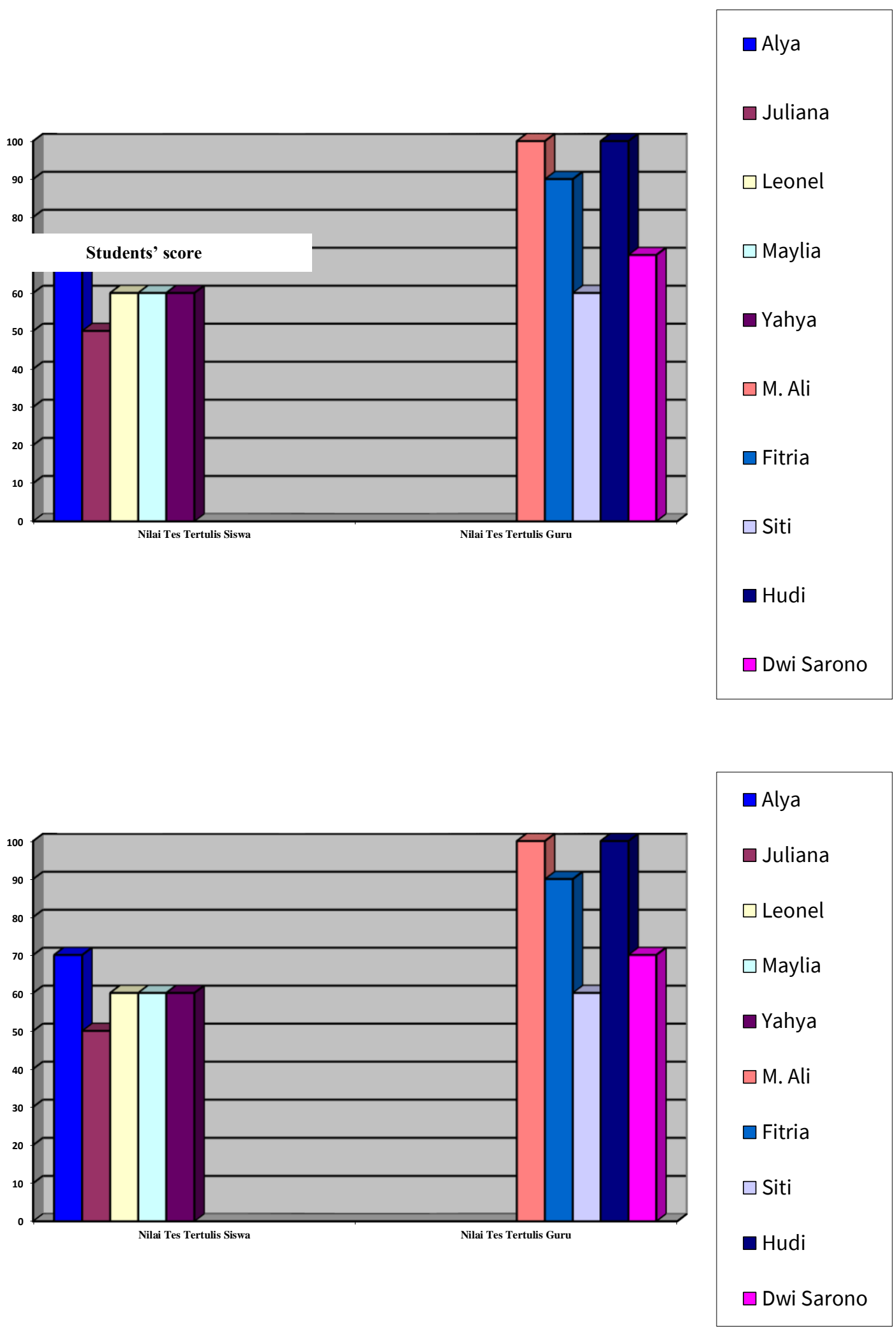

Picture 1. Results of Written Test

Here we can see that the teachers' score is higher than the student. There are 9 participants who get score $\geq 60$ and only 1 participant (Juliana Ira) who didn't pass the minimum completeness criteria. The average student score is 60 while the average 
teacher score is 84 . Although the average students' score meets the minimum criteria, but it still categorized as low. So we ask teachers to guide the students intensively during the next program namely Lets Practice.

In Lets Practice, we assessed students' ability in practicing the rhythmic gymnastics movements based on the tutorial video. Here are the results.
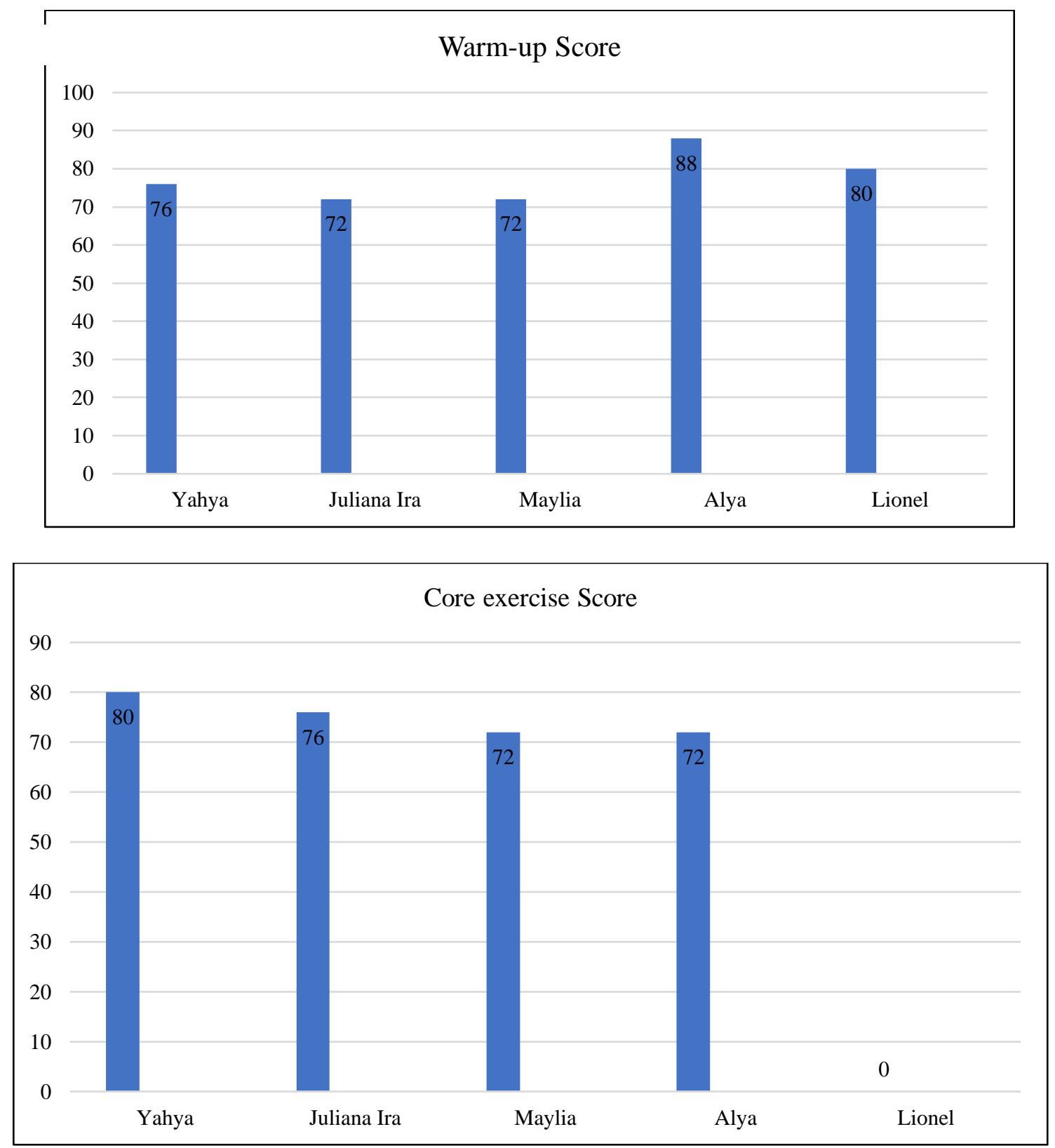


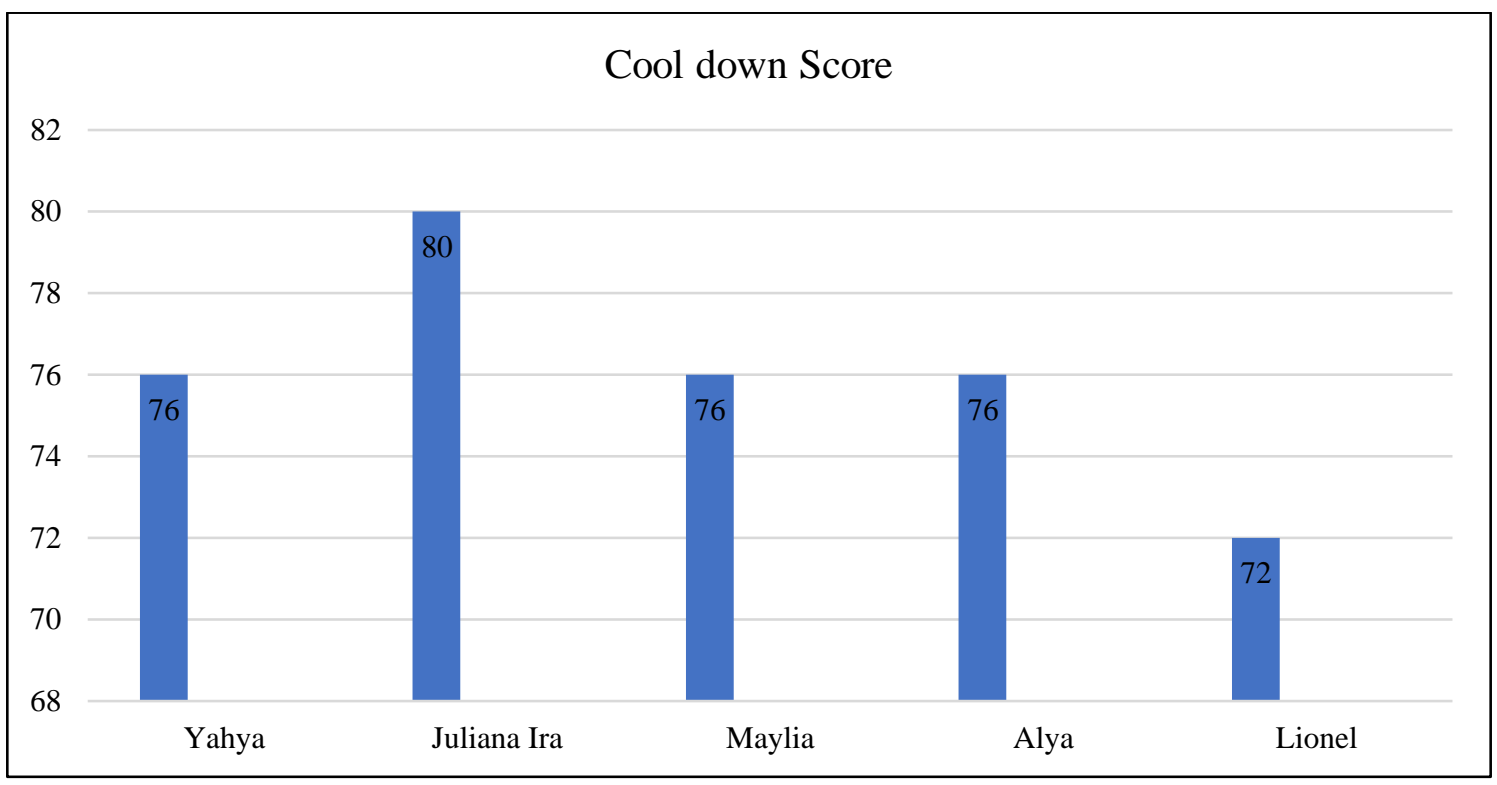

Picture 2. Results of Performance Test; a) Warm-up Score, b) Core exercise Score; c) Cooldown Score

Based on the results above, it is known that $100 \%$ students passed the minimum completeness criteria for warm-up and cool-down movements, and $80 \%$ students passed the minimum completeness criteria for core exercise movements. The average warm up score is 77,6 , while the average of core exercise score is 60 and the average of cool down score is 76 . The average core exercise score is low because there was 1 student (Lionel) who didn't submit his practice video. Lionel said he didn't submit the video due to the lack of helper in taking the video before the deadline. But actually, he knew how to practice it. Overall average score is 71,2 .

Generally, the aspect of Orderliness of Movement Sequences had a higher score than other aspect. It means that all students understand and can memorize the whole movements of the rhythmic gymnastics. Other aspects like Movement accuracy, Movement-Lyrics Compatibility, Movement-Rhythm Compatibility, and Movement Flexibility can be boosted its scores with some strategies. Habituation and intensive guidance from the parents \&/ teacher play the key role in boosting students' ability for doing these adaptive rhythmic gymnastics. The condition of blind and low vision students requires habituation in doing motoric movements, so that when practicing a movement that has never been done before, it needs direction by the touch of another person. Parents or supervising teachers can refer to the guidance book that we have compiled to instruct students to do gymnastic movements. With tactual (tactile) and auditory direction (both song rhythm and parental / supervisor explanation), students will be more flexible in practicing the movements so that their motor skills can improve progressively.

To ensure the sustainability of this program, we coordinated with the teachers to arrange ETAS (Expert Team of Adaptive Sport) organizational structure. The short-term goal of establishing the ETAS organizational structure is so that rhythmic gymnastics can 
be carried out regularly. In addition, if there are new blind students registered, old participants can become gymnastics tutors.

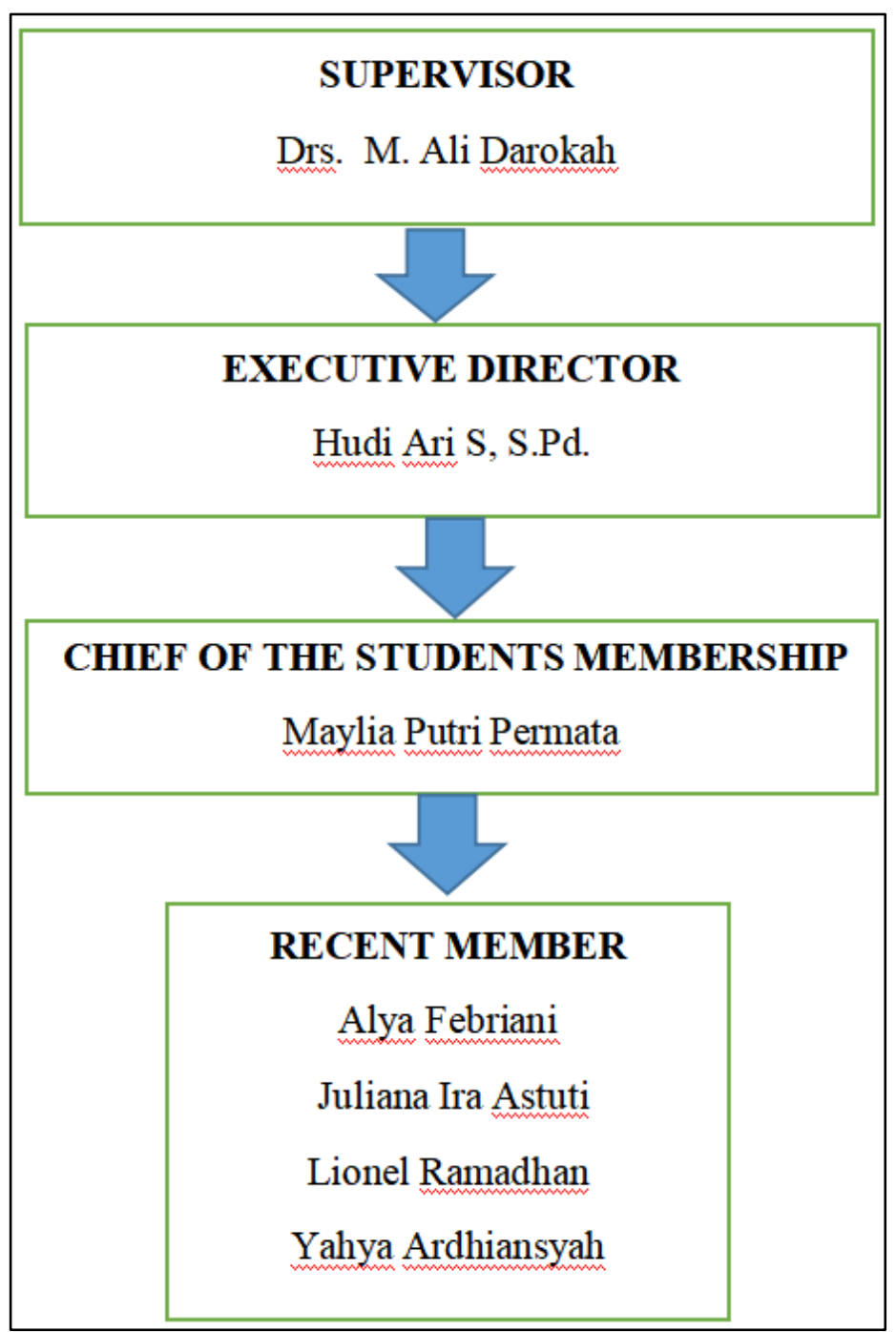

Picture 3. ETAS organizational structure batch 2020

The existence of ETAS also has long-term goal to become a new extracurricular which will consist of all blind students at SMP MIS Surakarta. The supervisor of this extracurricular is Mr. Hudi Ari S, S.Pd as one of the Special Guidance teacher a who has participated in a whole series of debriefing programs. Blind students in this extracurricular activity are expected to cultivate joint exercise activities among blind students as well as conduct peer tutoring. Meanwhile, the teacher who act as the extracurricular coach is expected to be a companion and guide, so that the spirit of exercising among blind students is maintained from year to year.

\section{Conclusion}

Based on the results above, it can be stated that The Adaptive Physical Education Implementation Program in the form of rhythmic gymnastics can run well at the SMP MIS Surakarta. This is evidenced by the results of written test done by students and teachers 
also performance test done by the students at each end of the 2 sessions. Quantitatively, the average students score is 60 while the average teachers score is 84 for the written test, and the average students score for performance test is 71,2 which is considered as skilled. Qualitatively, all students understand and can memorize the whole movements of the rhythmic gymnastics. Of course habituation and parental/teacher guidance is needed to boost students' ability in practicing the movements so that their motor skills can improve progressively. To ensure the sustainability of the program, we arrange ETAS organizational structure that aims to encourage students to continue their rhythmic gymnastics habits and is expected to be the initial extracurricular activities namely adaptive sports for blind students.

\section{References}

Douda H, Tokmakidis S, Tsigilis N. (2002) Effects of specific training on muscle strength and flexibility of rhythmic sports and artistic female gymnasts. Coach Sport Sci J. Vol. 4. No.1. Page 23-27.

Lowenfeld B. (1952) The Child Who Is Blind. Exceptional Children. Vol. 19 No. 3. Page 96102.

Oliver, S.M. (2020). Rekomendasi Jenis Olahraga di Tengah Pandemi Covid-19. https://primayahospital.com/covid-19/olahraga-di-tengah-pandemi/. Accessed at Thursday $27^{\text {th }}$ August 2020, 11.50 Western Indonesia Time.

Pane, B. S. (2015). Peranan Olahraga dalam Meningkatkan Kesehatan. Jurnal Pengabdian kepada Masyarakat. Vol. 21. No. 79. Page 1-4.

Prasetyo, Y. (2013). Kesadaran Masyarakat Berolahraga untuk Peningkatan Kesehatan dan Pembangunan Nasional. Jurnal Medikora. Vol 11. No 2. Page 219-228.

Santoso \& Anandaputra. (2017). Hubungan Intensitas Olahraga dengan Daya Konsentrasi Belajar Siswa/Siswi Kelas 10 dan 11 SMAN 5 Depok Jawa Barat. Jurnal Kedokteran dan Kesehatan. Vol. 13. No 1. Page 1-9.

Utomo. (2016). Pendidikan Jasmani Adaptif Bagi Anak Berkebutuhan Khusus Berwawasan Kebangsaan. Prosiding Seminar Internasional Pendidikan Berbasis Nilai-Nilai Kebangsaan. Universitas Lambung Mangkurat, Banjarmasin.

Winnick, J. \& Porretta, D. (2017). Adapted Physical Education and Sport. Human Kinetics Publisher, Illinois. 